Research Article

\title{
Association of Deficiency of Maternal Vitamin D Levels with Severity of Preeclampsia
}

\author{
Shilpa Jindal', Jasmine Chawla Sharma ${ }^{2}$, Manisha Sharma $^{3}$
}

${ }^{1}$ DNB Student, ${ }^{2}$ CMO NFSG, ${ }^{3}$ Senior Specialist, Department of Obstetrics \& Gynaecology, Hindurao Hospital.

DOI: https://doi.org/10.24321/2455.7048.201913

\section{I $\quad \mathbf{N} \quad \mathbf{F} \quad \mathbf{O}$}

\section{Corresponding Author:}

Jasmine Chawla Sharma, Department of Obstetrics \& Gynaecology, Hindurao Hospital.

E-mail Id:

drjasminechawla@gmail.com

Orcid Id:

https://orcid.org/0000-0002-7291-451X

How to cite this article:

Jindal S, Sharma JC, Sharma M. Association of Deficiency of Maternal Vitamin D Levels with Severity of Preeclampsia. Epidem Int 2019; 4(3): 10-16.

Date of Submission: 2019-11-04

Date of Acceptance: 2019-11-21

\section{$\begin{array}{llllllllll}\mathbf{A} & \mathbf{B} & \mathbf{S} & \mathbf{T} & \mathbf{R} & \mathbf{A} & \mathbf{C} & \mathbf{T}\end{array}$}

Introduction: Preeclampsia remains to be an important cause of maternal morbidity and mortality in both the developing and developed world. It is imperative to devise preventive strategies to reduce the burden of this disease. Vitamin D deficiency has emerged as an important inflammatory mediator in its pathogenesis.

Objective: To find an association between the severity of preeclampsia and vitamin D deficiency amongst women attending a tertiary hospital in northern India.

Material \& Methods: this was a prospective comparative observational study. 125 women of preeclampsia and 125 controls were enrolled in the study after due written consent. The women of preelampsia were further divided into preeclampsia with or without severe features. After history, examination and relevant routine investigations, both groups underwent testing for vitamin D. Statistical analysis was conducted with the statistical package for the social science software version SPSS 20.0. The comparison of normally distributed continuous variables between the two groups was performed using Student's t test and for more than two groups comparison done through ANOVA test. For all statistical tests, a $\mathrm{p}$ value less than 0.05 was taken to indicate a significant difference/ association.

Result: $80 \%$ subjects of study group were significantly more vitamin D deficient as compared to $68 \%$ of controls ( $p$-value $=0.03$ ). Patients with preeclampsia with severe features had significantly lower levels of Vitamin D as compared to controls indicating that increased vitamin D deficiency was associated with increased severity of preeclampsia. None of the cases with severe preeclampsia had normal levels of Vitamin D. This was statistically significant ( $p$-value=0.046).

Conclusion: Severe pre-eclampsia was significantly associated with Vit $\mathrm{D}$ deficiency. Prevention of Vitamin $\mathrm{D}$ deficiency could be beneficial to prevent pre-eclampsia but community intervention studies are required.

Keywords: Preeclampsia, Vit D Deficiency, Maternal Mortality 


\section{Introduction}

According to WHO, mortality due to pregnancy or childbirth related complications are 830 women per day worldwide. Due to pregnancy and its complications, roughly 3,03,000 women died in year 2015 out of which 99\% mortality occurred in developing countries. ${ }^{1}$ Maternal mortality rate in India is 122 per 100,000 live births. ${ }^{2}$ Preeclampsia is one of the major causes of perinatal mortality, accounting for approximately $25 \%$ of overall fetal and early neonatal deaths. ${ }^{3}$ According to $\mathrm{WHO}$, the incidence of pre-eclampsia is $2.8 \%$ of live births in India and $0.4 \%$ of live births in developed countries like UK. ${ }^{4}$

Pre-eclampsia is a syndrome that chiefly includes the development of new onset hypertension in the second half of pregnancy and is considered to be a multifactorial disease whose cause remains unknown. ${ }^{5}$ Central to its pathogenesis is the occurrence of widespread endothelial dysfunction and vascular capillary leakage. There are many risk factors for pre-eclampsia like primigravida, multifetal pregnancy, advanced maternal age (>than 40 years), obesity, in vitro fertilization etc. ${ }^{5}$ There are multiple hypothesis regarding etiology of pre-eclampsia, one of which is hypovitaminosis $D$ in pregnancy. ${ }^{6-8}$

Hypovitaminosis D is associated with various health problems like diabetes, cardiovascular diseases, neurological \& neuropsychiatry disorders and several cancers in general population. ${ }^{9}$ In pregnancy, some studies have shown that its deficiency is associated with Pre-eclampsia, gestational diabetes mellitus, preterm birth, lower segment caesarian section, preterm labour and increased risk of bacterial vaginosis. ${ }^{10}$ As per Evans KN et al. (2004), vitamin D plays a role in implantation and placental function potentially due to its angiogenic, immunomodulatory and anti-inflammatory effects, ${ }^{11}$ which may explain its role in preeclampsia.

\section{Materials and Methods \\ Study Design}

A hospital based prospective, comparative observational study.

\section{Study Setting}

The study was conducted in a tertiary care 980 bedded hospital which primarily caters to a population of about 18 lakh-largely from northern part of Delhi, though its services are also utilized by patients from rural areas, towns from neighbouring states of Uttar Pradesh, Haryana \& Rajasthan. The annual attendance in the OPD of the department of obstetrics and gynaecology is around 34,000 patients per annum. The average delivery rate in the hospital is approximately 10,000 per year. This study was done in the Department of Obstetrics \& Gynaecology in collaboration with the Department of Microbiology.

\section{Period of Study}

From September 2017- May 2019 (21 months).

\section{Study Population}

All antenatal cases with gestational age $>20 w k$ between 18-35years of age and singleton pregnancy attending antenatal clinic during the study period.

\section{Study Tool}

Study tool was a pre-structured proforma and it consisted of 3 parts: clinical evaluation, diagnostic and maternal \& fetal outcome.

- Clinical evaluation part comprised of detailed history of the patient including age, demographic profile, history of present illness, menstrual history, obstetric history, past history, family history, general examination, obstetric examination and systemic examination.

- Diagnostic evaluation part comprised of investigationsComplete Blood Count with platelets, URINE PROTEIN, Renal Function Tests, Liver Function Tests, Serum Electrolytes, Random Blood Sugar, Total serum Vitamin D level, Prothrombin Time/ INR, Obstetric Ultrasound \& Color Doppler, Fundus Examination.

- Outcome part comprised of maternal outcome in terms of mode \& timing of delivery, maternal complications and neonatal outcome-Intrauterine Death, IUGR, Fetal distress, Low Birth Weight, Neonatal death, APGAR score \& Neonatal ICU admission.

\section{Operational Definitions}

1. Diagnostic Criteria of Preeclampsia, classification of severity Definition Of Proteinuria were used as per ACOG CRITERIA 2013.

\section{Definition of Vitamin D Deficiency:}

In the present study, after consultation with microbiologist and review of literature (ritu g) the following levels were used to categorize the level of vitamin $D$ as per the endocrinology society clinical guidelines. ${ }^{12}$

- $\quad<20 \mathrm{ng} / \mathrm{ml}$ - Vitamin D Deficient

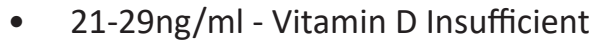

- 30-100ng/ml - Sufficient Vitamin D Level

Additional operational definitions used in the study given as supplemental document.

\section{Exclusion Criteria}

Diagnosed cases of preexisting essential hypertension or hypertension diagnosed at $<20$ weeks of gestation, Preexisting diabetes mellitus, Renal disease, Liver disease, Thyroid disorder, Epilepsy, Multiple pregnancy, Placenta previa, morbidly adherent placenta (placenta accrete/ increta/ percreta), Previously diagnosed patients of 
hypovitaminosis. Any other medical co morbidities are excluded.

\section{Ethical Consideration}

The study participants were explained about the objectives and purpose of the study. Informed written consent was taken from each participant prior to data collection. Privacy and confidentiality of each participant was assured. The study received ethical approval from the Institutional Ethics Committee.

\section{Method of Collection of Data}

Patients were enrolled only after fulfilling the inclusion criteria of the study, taking informed written consent and explaining the procedure to them. Pre structured Proforma as described above was used to record the details of the patient.

Equal numbers of normotensive pregnant females were taken as comparative control group.

This population was divided in to two groups.

Group 1: Healthy normotensive (normal) pregnant women

Group 2: Diagnosed cases of preeclampsia which was further divided according to severity into severe and nonsevere groups.

These two groups were further divided according to total serum vitamin D levels into following groups:

- $\quad<20 \mathrm{ng} / \mathrm{ml}$

- $20-29 \mathrm{ng} / \mathrm{ml}$

- 30-100ng/ml

Detailed history of the patient including age, demographic profile, history of present illness, menstrual history, obstetric history, past history and family history was taken. After a detailed history, general examination, obstetric examination and systemic examination was done.

All the enrolled pregnant women underwent the following investigations-CBC with platelets, URINE PROTEIN, RFT, LFT, SE, RBS, Total Vitamin D level, PT/ INR, USG OBS.COLOUR DOPPLER, FUNDUS EXAMINATION.

For analysis of total vitamin D level, $2 \mathrm{ml}$ blood sample in plain vial on empty stomach was collected and then sample was centrifuged after formation of complete clot. After separation of serum, vitamin D estimation was done in fully automated cobas e411 analyzer based on electrochemiluminescence technology.

The groups were matched according to age, gravidity, parity, maternal weight \& gestational age.

The study population were followed until delivery and early postpartum period and their babies till early neonatal period (0-6 days of age).

\section{Statistical Methods}

\section{Sample Size}

It was calculated by open epi online software using formula:

$\left.\mathrm{n}=\mathrm{z}^{2}{ }_{1-\alpha / 2}\left[\left(1-\mathrm{P}_{1}\right) / \mathrm{P}_{1}\right)+\left(\left(1-\mathrm{P}_{2}\right) / \mathrm{P}_{2}\right)\right]$

$[\log (1-d)]^{2}$

Here

$\mathrm{z}^{2}{ }_{1-\alpha / 2}=1.96$.

$\mathrm{P}_{1}=$ Proportion of pre eclamptic women deficient in vitamin $D$ [taking reference of Goel P et al (2016) [14] is $100 \%$.

$\mathrm{P}_{2}=$ Proportion of non preeclamptic women deficient in vitamin D, [Goel P et al. (2016) (48)] is 92\%, Denominator is $5 \%$.

By above formula, sample size was 121 in each group and total sample size was 242 . For sake of convenience, sample size of 125 patients in each group (total 250) was taken.

Data was collected; compiled, and analyzed. Data collected during the study was tabulated in Microsoft Excel. Statistical analysis was conducted with the statistical package for the social science software version SPSS 20.0. Continuous variables were presented as mean $\pm S D$. Categorical variables were expressed as frequencies and percentages. Nominal categorical data between the groups were compared using Chi-square test. The comparison of normally distributed continuous variables between the two groups was performed using Student's t test and for more than two groups comparison done through ANOVA test. For all statistical tests, a p-value less than 0.05 was taken to indicate a significant difference/ association.

\section{Result}

Table I.Distribution of age, BMI and gestational age at booking between study group and control group

\begin{tabular}{|c|c|c|c|}
\hline & $\begin{array}{l}\text { Study Group } \\
\qquad(n=125) \\
\text { Mean } \pm S D\end{array}$ & $\begin{array}{c}\text { Controls } \\
(n=125) \\
\text { Mean } \pm S D\end{array}$ & p-value* \\
\hline $\begin{array}{c}\text { Age } \\
\text { (years) }\end{array}$ & $23.87 \pm 2.59$ & $24.19 \pm 2.93$ & 0.36 \\
\hline $\begin{array}{c}\text { Body mass } \\
\text { index (kg/ } \\
\mathrm{m} 2)\end{array}$ & $23.63 \pm 1.89$ & $23.27 \pm 1.85$ & 0.13 \\
\hline $\begin{array}{l}\text { Mean period } \\
\text { of gestation } \\
\text { at booking } \\
\text { (wks.) }\end{array}$ & $32.15 \pm 1.28$ & $32.22 \pm 1.27$ & \\
\hline
\end{tabular}

As can be seen in table 1, women in both the study and control groups were of comparable age, $\mathrm{BMI}$ and gestational age. 
Table 2.Gravidity and booking status in controls and study group

\begin{tabular}{|c|c|c|c|c|c|}
\hline \multirow[b]{2}{*}{ Variable } & & \multicolumn{2}{|c|}{ Study Group N=125 (\%) } & \multirow{2}{*}{$\begin{array}{c}\text { Controls } \\
\mathrm{N}=125(\%)\end{array}$} & \multirow[b]{2}{*}{ p-value* } \\
\hline & & $\begin{array}{l}\text { PE without severe } \\
\text { feature } N=89(\%)\end{array}$ & $\begin{array}{c}\text { PE with severe } \\
\text { feature } N=36(\%)\end{array}$ & & \\
\hline \multirow{3}{*}{ Gravidity } & G1 & $62(69.66)$ & $20(55.56)$ & $68(54.4)$ & \multirow{3}{*}{0.19} \\
\hline & $\mathrm{G} 2$ & $25(28.09)$ & $14(38.89)$ & $49(39.2)$ & \\
\hline & G3 & $2(2.25)$ & $2(5.56)$ & $8(6.4)$ & \\
\hline \multirow[t]{2}{*}{ Booking Status } & Booked & $57(64.05)$ & $16(44.44)$ & $98(78.4)$ & \multirow{2}{*}{$<0.001$} \\
\hline & Unbooked & $32(35.95)$ & $20(55.55)$ & $27(21.6)$ & \\
\hline
\end{tabular}

${ }^{*} \chi 2$ test, $p$-value $<0.05$ significant.

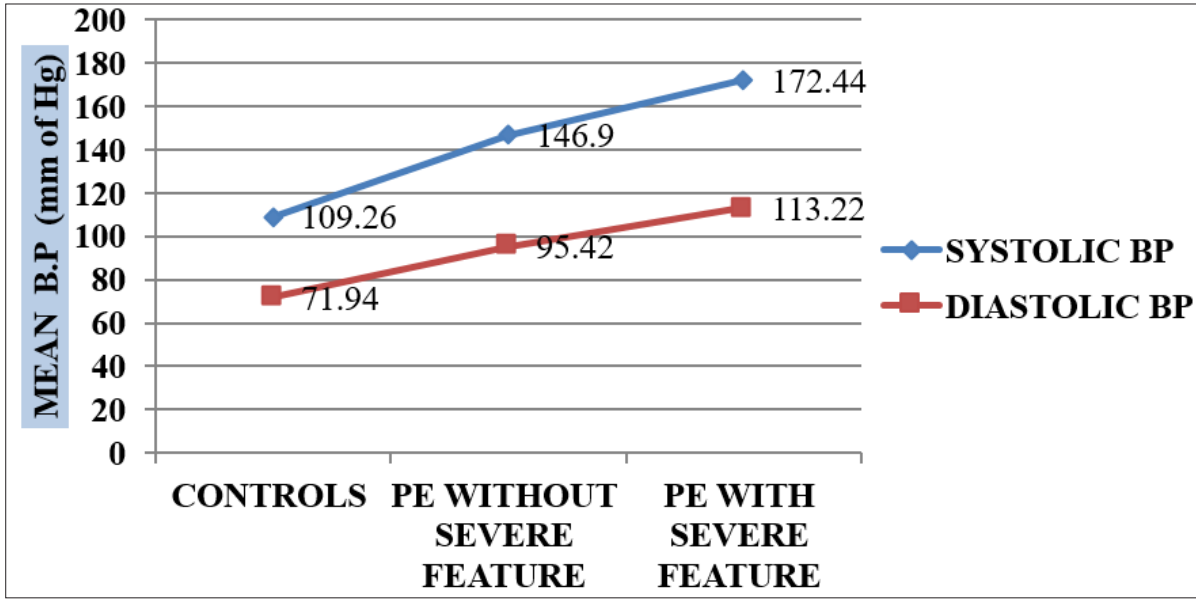

Figure I.Line diagram showing distribution of systolic and diastolic BP in controls and study group

Looking at the distribution of severity in our study, 71.2 $\%$ were patients of preeclampsia without severe features and $28.8 \%$ were patients with preeclampsia with severe features.

As can be seen in Figure 1, our study also showed that there was a statistically significant increase in systolic and diastolic BP in severe PE as compared to mild PE and control ( $p$-value $=0.0001$ ).

Table 3.Mean serum vitamin D level in various groups of patients

\begin{tabular}{|c|c|c|}
\hline $\begin{array}{c}\text { Groups of Patients } \\
\text { (N) }\end{array}$ & $\begin{array}{c}\text { Vitamin D } \\
\text { (mean } \pm \text { SD) ng/ml }\end{array}$ & \multirow{2}{*}{ p-value* } \\
\cline { 1 - 2 } $\begin{array}{c}\text { Normotensive } \\
\text { Controls (125) }\end{array}$ & $19.08 \pm 9.47$ & \multirow{2}{*}{$<0.0001$} \\
\cline { 1 - 2 } $\begin{array}{c}\text { PE Without Severe } \\
\text { Features (89) }\end{array}$ & $14.33 \pm 7.78$ & \\
\cline { 1 - 2 } $\begin{array}{c}\text { PE With Severe } \\
\text { Features (36) }\end{array}$ & $8.59 \pm 5.62$ & \\
\hline \multicolumn{2}{|c|}{ *paired t test, p-value $<0.05$ significant }
\end{tabular}

As can be seen in table 3, mean serum Vitamin D level was found to be lower in the preeclamptic subjects with and without severe features as compared to normotensive patients. The mean value in patients with severe features of preeclampsia was $8.59 \pm 5.62 \mathrm{ng} / \mathrm{ml}$, in patients without severe features of preeclampsia was $14.33 \pm 7.78 \mathrm{ng} / \mathrm{ml}$ and in controls was $19.08 \pm 9.47 \mathrm{ng} / \mathrm{ml}$. This difference was statistically significant ( $p$-value $<0.001$ ).

Table 4.Distribution of patients in study group and controls according to serum vitamin D levels

\begin{tabular}{|c|c|c|c|}
\hline $\begin{array}{c}\text { Vitamin D } \\
\text { (ng/ml) }\end{array}$ & $\begin{array}{c}\text { Study Group } \\
\mathbf{N}=125(\%)\end{array}$ & $\begin{array}{c}\text { Controls } \\
\mathbf{N}=125(\%)\end{array}$ & p-value* \\
\hline$<20$ & $100(80)$ & $85(68)$ & 0.03 \\
\hline $21-29$ & $18(14.4)$ & $25(20)$ & 0.41 \\
\hline $30-100$ & $7(5.6)$ & $15(12)$ & 0.02 \\
\hline
\end{tabular}

Table 4, shows that more numbers of subjects of study group (80\%) were vitamin D deficient as compared to $68 \%$ of controls. This difference was statistically significant ( $p$ -value $=0.03$ ). It can also be seen that $5.6 \%$ of study group $\& 12 \%$ of controls had sufficient levels of vitamin D. It was statistically significant when compared to controls ( $p$-value $=0.02)$. This result showed that more numbers of subjects of control group had sufficient levels of vitamin D. 
Table 5.Distribution of patients of preeclampsia without severe features and controls according to serum vitamin D levels

\begin{tabular}{|c|c|c|c|}
\hline $\begin{array}{l}\text { S. Vitamin D } \\
\text { Level (ng/ml) }\end{array}$ & $\begin{array}{c}\text { PE Without } \\
\text { Severe Feature } \\
\mathbf{N}=\mathbf{8 9}(\%)\end{array}$ & $\begin{array}{c}\text { Controls } \\
\mathrm{N}=125 \text { (\%) }\end{array}$ & p-value* \\
\hline$<20$ & 69 (77.53) & $85(68)$ & \multirow{3}{*}{0.30} \\
\hline $21-29$ & 13 (14.61) & $25(20)$ & \\
\hline $30-100$ & $7(7.87)$ & $15(12)$ & \\
\hline
\end{tabular}

${ }^{*} \chi 2$ test, $p$-value $<0.05$ significant

Table 5, shows that $68 \%$ of controls \& $77.53 \%$ of preeclampsia subjects without severe features were vitamin D deficient. Vitamin D level of preeclamptic women with mild features when compared with controls were not found to be significant ( $p$-value=0.30).

Table 6.Distribution of patients of preeclampsia with severe features and controls according to serum vitamin D levels

\begin{tabular}{|c|c|c|c|}
\hline $\begin{array}{l}\text { S. Vitamin } \\
\text { D level } \\
\text { (ng/ml) }\end{array}$ & $\begin{array}{c}\text { PE with severe } \\
\text { feature } \\
N=36(\%)\end{array}$ & $\begin{array}{c}\text { Controls } \\
\mathrm{N}=125(\%)\end{array}$ & p-value* \\
\hline$<20$ & $31(86.11)$ & $85(68)$ & \multirow{3}{*}{0.046} \\
\hline $21-29$ & $5(13.89)$ & $25(20)$ & \\
\hline $30-100$ & $0(0)$ & $15(12)$ & \\
\hline
\end{tabular}

As shown in table $6,68 \%$ of controls \& $86.11 \%$ of preeclampsia subjects with severe features were vitamin $D$ deficient. This result showed that more patients of preeclampia with severe features were deficient in vitamin D levels as compared to controls. This was statistically significant ( $p$-value=0.046).

\section{Discussion}

Preeclampsia is taking an enormous toll in developing country like India as well as the western society. Although manageable and preventable, these hypertensive disorders remain the leading cause of maternal death. Research over last two decade proved the role of inflammatory mediators in the pathophysiology of preeclampsia. Vitamin D is one of those parameters. In view of this, the present study has been taken up to assess the association between deficiency of vitamin D and the severity of preelampsia and to assess if it can be of some prognostic significance in preeclampsia.

In terms of age, BMI, Mean gestational age there was no difference in the study and control group indicating that they were comparable. Similarly, Sahu M et al. (2017) ${ }^{13}$ and Goel P et al. (2016) ${ }^{14}$ observed no significant difference in their age group. Like our study, Goel P et al. $(2016)^{14}$ and Bakacak M et al. (2015) ${ }^{15}$ also observed no significant difference of $\mathrm{BMI}$ in study and control group.

The distribution of patients of preeclampsia with and without severe features in our study was similar to Baror S et al. (2017), ${ }^{16}$ Rao et al. (2018), ${ }^{17}$ Mehta S et al. (2016) and Arumaikannu J et al. $(2018)^{19} 55.55 \%$ subjects with preeclampsia with severe features and $21.6 \%$ controls were unbooked. It was statistically significant ( $p$ value $<0.0001$ ) indicating more patients with severe preeclampsia were unbooked than booked ( $55.55 \%$ and $44.44 \%$ ). This reflects that timely booking is an important determinant of the severity of preeclampsia thereby enabling the reduction in its morbidity. Also, keeping in mind the very definition of preeclampsia it was not suprising to note that the mean systolic BP and Diastolic BP was significantly higher in the group of preeclampsia with severe features as compared to controls. Our study is similar in terms of mean SBP \& DBP to studies of Samir Abdalla A et al. (2018), ${ }^{20}$ Bakacak M et al. (2015), ${ }^{15}$ Sadin B et al (2015) ${ }^{21}$ and Xiao JP et al (2017). ${ }^{22}$

The significant difference in the mean vitamin $D$ levels observed in our study group as compared to the control group indicated a strong association between deficiency of Vitamin D and preeclampsia. Our study finding was consistent with the studies conducted by Sharma $\mathrm{N}$ et al. (2019), ${ }^{23}$ Choudhary N et al. (2018), ${ }^{24}$ Sahu M et al. (2017), ${ }^{13}$ Baror S et al. (2017), ${ }^{16}$ Kumari A et al. (2017), ${ }^{25}$ Goel P et al. (2016), ${ }^{14}$ Sadin B et al. (2015), ${ }^{21}$ Singla et al. $(2015)^{26}$ and Bakacak et al. (2015). ${ }^{15}$ Our study also demonstrated that though vitamin D deficiency was common in all antenatal patients but it was significantly more prevalent in preeclamptic women. This was comparable to the results were obtained by Rao et al. (2018) who showed the women with preeclampsia with vitamin deficiency were $67.5 \%{ }^{17}$ similar to Baror S et al. (2017) reporting $72 \%^{16}$ and Mehta S. Singh A et al. (2016) reporting a prevalence of $90 \% .{ }^{18}$ Sadin B et al. $(2015)^{21}$ observed that serum Vitamin D level less than $10 \mathrm{ng} / \mathrm{ml}$ was associated with a 15 times increase in the odds ratio of preeclampsia. Unlike our study, Hasheimpour S et al. (2017), ${ }^{27}$ Goel P et al. (2016) $)^{14}$ and Shand AW et al. (2010) ${ }^{28}$ observed no significant difference of Vitamin D in preeclamptic women as compared to controls, Looking at table 5 and 6 , it can be observed that severity of preeclampsia correlated with deficiency of vitamin D level. None of the cases with severe preeclampsia had normal levels of Vitamin $D$ which was statistically significant ( $p$-value=0.046). This was comparable to studies by Rao et al. (2018), ${ }^{17}$ Baror S et al. (2017) ${ }^{16}$ and Mehta S et al. (2016). ${ }^{18}$ Ullah et al. (2013) ${ }^{29}$ in his study concluded that the odds of developing preeclampsia and eclampsia increased upto 5 times in women with Vitamin D insufficiency. Similarly, Singh A et al. (2016) ${ }^{30}$ and Mehmood et al. $(2016)^{31}(p$-value $=0.045)$ also found that most of the 
patients of severe preeclampsia had very low $(<10 \mathrm{ng} / \mathrm{ml})$ Vitamin D level.

\section{Conclusion}

Our study showed a significant association of Vitamin D deficiency with preeclampsia and its severity. As preeclampsia remains to be an important cause of maternal and fetal mortality and morbidity, it is imperative that preventive strategies may be employed to reduce the burden of this condition. Correction of vitamin D deficiency amongst antenatal women may provide such an opportunity.

\section{Conflict of Interest: None}

\section{References}

1. Alkema L, Chou D, Hogan D, Zhang S, Moller AB, Gemmmill A et al. Global, regional and national levels and trends in maternal mortality between 1990 and 2015, with scenario-based projections to 2030: a systematic analysis by the UN Maternal Mortality Estimation InterAgency Group. Lancet 2016; 387(10017): 462-474. Available from: https://www.thelancet.com/journals/ lancet/article/PIIS0140-6736(15)00838-7/fulltext [PubMed/ Google Scholar].

2. Sample Registration Bulletin/ SRS_Bulletins/ MMR Bulletin-2015-17. Available from: http://censusindia. gov.in/vital_statistics/SRS_Bulletins/Bulletins.html.

3. Hodgins S. Pre-eclampsia as underlying cause for perinatal deaths: time for action. Glob Health Sci Pract 2015; 3(4): 525-527. Available from: http://www. ghspjournal.org/content/3/4/525.abstract [PubMed/ Google Scholar/ ResearchGate].

4. World Health Organisation. Global burden of hypertensive disorders of pregnancy in the year 2000. Geneva; 2003. Available from: https://pdfs. semanticscholar.org/2d77/75c57e6a91969156c78cb3 8e37a95093b351.pdf [Google Scholar].

5. American College of Obstetricians and Gynaecologists. Task Force on Hypertension in Pregnancy. Hypertension in Pregnancy. Report of the American College of Obstetricians and Gynecologists' Task Force on Hypertension in Pregnancy. Obstet Gynecol 2013; 122(5): 1122-1131. Available from: https://insights. ovid.com/article/00006250-201311000-00036 [PubMed].

6. Bodnar LM, Catov JM, Simhan HN, Holick MF, Powers RW, Roberts JM. Maternal Vitamin D Deficiency Increases the Risk of Preeclampsia. J Clin Endocrinol Metab 2007; 92(9): 3517-3522. Available from: https:// academic.oup.com/jcem/article/92/9/3517/2597795 [PubMed/ Google Scholar].

7. Domaracki P, Sadlecki P, Odrowaz-Sypniewska G, Dzikowska E, Walentowicz P, Siodmiak J et al. Serum 25(OH) Vitamin D Levels in Polish Women during
Pregnancies Complicated by Hypertensive Disorders and Gestational Diabetes. Int J Mol Sci 2016; 17(10): 1574. Available from: https://www.mdpi.com/14220067/17/10/1574 [PubMed/ Google Scholar].

8. Behjat Sasan S, Zandvakili F, Soufizadeh N, Baybordi E. The Effects of Vitamin D Supplement on Prevention of Recurrence of Preeclampsia in Pregnant Women with a History of Preeclampsia. Obstet Gynecol Int 2017; 8249264. [PubMed/ Google Scholar].

9. Gil A, Diaz JP, Mesa MD. Vitamin D: Classic and Novel Actions. Ann Nutr Metab 2018; 72(2): 87-95. Available from: https://www.karger.com/Article/FullText/486536 [PubMed/ Google Scholar].

10. Kaushal M, Magon N. Vitamin D in pregnancy: $A$ metabolic outlook. Indian J Endocr Metab 2013; 17(1): 76-82. Available from: http://www.ijem.in/article. asp? issn=2230-8210; year=2013; volume $=17$;issue $=1 ; s$ page $=76$; epage $=82$; aulast $=$ Kaushal $[$ PubMed $/$ Google Scholar].

11. Evans KN, Bulmer JN, Kilby MD, Hewison M. Vitamin D and placental-decidual function. J Soc Gynecol Investig 2004; 11(5): 263-271. [PubMed/ Google Scholar].

12. Ritu G, Gupta A. Vitamin D Deficiency in India: Prevalence, Causalities and Interventions. Nutrients 2014; 6(2): 729-775. Available from: [PubMed/ Google Scholar].

13. Sahu M, Tripathy S, Bhuyan P. Association of maternal serum vitamin D level with preeclampsia or eclampsia and its relationship with neonatal outcome and neonatal serum calcium level. Int J Reprod Contracept Obstet Gynecol 2017; 6(12): 5580-5586. Available from: https://www.ijrcog.org/index.php/ijrcog/article/ view/3901.

14. Goel P, Garg G, Kaur J, Mehra R, Tandon R, Huria A. Association of vitamin $D$ deficiency during pregnancy with preeclampsia and eclampsia. Int J Reprod Contracept Obstet Gynecol 2016; 5(9): 3046-3050. Available from: https://www.ijrcog.org/index.php/ ijrcog/article/view/1592.

15. Bakacak M, Serin S, Ercan O, Köstü B, Avci F, Kılınç M et al. Comparison of Vitamin D levels in cases with preeclampsia, eclampsia and healthy pregnant women. Int J Clin Exp Med 2015; 8(9): 16280-16286. [PubMed/ Google Scholar/ ResearchGate].

16. Baror S, Rajoria L, Hemani S, Vyas J, Sharma A, Baghotia P. Role of Vitamin D in Predicting the Risk of Preeclampsia. IJSR 2017; 6(4): 640-642. Available from: https://www.worldwidejournals.com/internationaljournal-of-scientific-research-(IJSR)/article/role-ofvitamin-d-in-predicting-the-risk-of-preeclampsia/ MTA2Nzc=/.

17. Rao A, Ghose S, Rathod S. Correlation between Serum Vitamin D levels and hypertensive disorders in pregnancy 
in primigravida in third trimester. J obstet Gynecol 2018; 4(2): 21-28. Available from: http://medresearch.in/ index.php/JOOG/article/view/2650/3672.

18. Mehta S, Mahala M, Sharma M. Maternal Vitamin D levels in Hypertensive disorder of Pregnancy and Healthy pregnant women. IOSR Journal of Dental and Medical Sciences 2016; 15(6): 86-88. Available from: https://pdfs.semanticscholar.org/ 480e/5b26715dbf2fcdc4a85d110b9a4d6a6aa9c5.pdf.

19. Arumaikannu J, Usha-Rani S, Shanthi S. Role of vitamin D in preeclampsia: Our experience. J Clin Obstet Gynaecol 2018; 2(2): 29-32. Available from: http:// www.gynaecologyjournal.com/articles/54/2-2-3-727. pdf.

20. SamirAbdalla A, Faris T, Elaziz AFA, Abdelhafiz AA. Ratio between Low Serum Maternal 25-Hydroxy vitamin D Concentration and the Risk of Preeclampsia. Egypt J Hosp Med 2018; 72(8): 5044-5049. Available from: http://ejhm.journals.ekb.eg/article_10285.html [Google Scholar].

21. Sadin B, Pourghassem Gargari B, Pourteymour Fard Tabrizi F. Vitamin D Status in Preeclamptic and Nonpreeclamptic Pregnant Women: a Case-Control Study in the North West of Iran. Health Promot Perspect 2015; 5(3): 183-190. [PubMed/ Google Scholar].

22. Xiao JP, Lv JX, Yin YX, Jhang L, Li WS, Tao T et al. Lower maternal and fetal vitamin $D$ status and higher placental and umbilical vitamin $D$ receptorexpression in preeclamptic pregnancies. Int J Clin Exp Pathol 2017; 10(11): 10841-10851. Available from: http://www. ijcep.com/files/ijcep0061372.pdf [Google Scholar].

23. Sharma N, Nath C, Mohammad J. Vitamin D status in pregnant women visiting a tertiary care center of North Eastern India. J Family Med Prim Care. 2019 Feb; 8(2): 356-360. Available from: https://www.ncbi. nlm.nih.gov/pmc/articles/PMC6436274/ [PubMed/ Google Scholar].

24. Choudhary N, Rastogi R, Joshi P. Comparative Study of Vitamin D Status and Fetomaternal Outcome in Preeclampsia/ Eclampsia and Normal Pregnant Women at Term. Indian Journal of Obstetrics and Gynecology 2018; 6(5): 478-485. Available from: https://rfppl. co.in/subscription/upload_pdf/Dr.\%20Nidhi\%20 Choudhary\%20(IJOG-7993-2018)_7735.pdf.

25. Kumari A, Mitra S, Tiwari HC, Srivastav R. Hypovitaminosis $D$ in pregnancy and its correlation with preeclampsia and gestational diabetes mellitus. Int J Reprod Contracept Obstet Gynecol 2017; 6(3): 890896. Available from: https://pdfs.semanticscholar. org/32e0/b0ed9b3de65bafc344ea65670bc8707db626. pdf[Google Scholar]

26. Singla R, Gurung P, Aggarwal N, Dutta U, Kochhar R. Relationship between preeclampsia and vitamin $\mathrm{D}$ deficiency: a case control study. Arch Gynecol Obstet 2015; 291(6): 1247-51. [PubMed/ Google Scholar].

27. Hashemipour S, Esmailzadehha N, Ziaee A, Khoeiniha $\mathrm{MH}$, Darvishgoftar E, Mesgari Z et al. The Relationship of Vitamin D and Calcium level with Preeclampsia Severity: A Case- control Study. Int J Pediatr 2017; 5(5): 5203-5210. [Google Scholar].

28. Shand AW, Nassar N, Dadelszen PV, Innis SM, Green TJ. Maternal vitamin D status in pregnancy and adverse pregnancy outcomes in a group at high risk for preeclampsia. BJOG 2010; 117(13): 1593-1598.Available from: https://obgyn.onlinelibrary.wiley.com/doi/ full/10.1111/j.1471-0528.2010.02742.x [PubMEd/ Google Scholar].

29. Ullah MI, Koch CA, Tamanna S, Rouf S, Shamsuddin L. Vitamin D Deficiency and the Risk of Pre eclampsia and Eclampsia in Bangladesh. Horm Metab Res 2013; 45(09):682-687. [PubMed/ Google Scholar].

30. Singh A, Mishra S, Aditya V, Srivastava R. Association of vitamin $D$ deficiency with occurrence of pre eclampsia among inpatients of tertiary care centre, Gorakhpur, Uttar Pradesh, India. Int J Reprod Contracept Obstet Gynecol 2016; 5(5): 1304-1308. Available from: https:// www.ijrcog.org/index.php/ijrcog/article/view/1008 [Google scholar].

31. Mehmood S, Karim SA. Vitamin D Deficiency during Pregnancy and its Relationship with Pre-Eclampsia, Eclampsia and Gestational Hypertension. Austin J Nutr Metab 2016; 3(2): 1040. Available from: https:// austinpublishinggroup.com/nutrition-metabolism/ fulltext/ajnm-v3-id1040.php. 